Article Type: Research Paper

\title{
Debit and Credit Cards: Money Velocity Risks
}

\author{
Hari Setia Putra*, Mutia Huljannah, Ali Anis, and Zul Azhar
}

Abstract: Payment system innovations as the efforts to meet the people's needs have recently risen several new non-cash-based payment instruments, such as card-based payment transactions. The upheaval of card-based non-cash transactions has indirectly shifted the role of cash in the society. This research aims to see the effect of cards as payment instruments represented by both debit and credit cards on money velocity in Indonesia within the period of $2016 \mathrm{M} 1$ to 2020M6 using the VECM (Vector Error Correction Model) analysis method. The research findings show that long-run card-based payment instrument has a significant effect on money circulation in Indonesia. It means that money velocity in Indonesia is not constant. Money velocity is a key concept in monetary theories and an important element for monetary analysis. Therefore, it is important for central bank to monitor and understand the money velocity trends to provide longterm benefits. The research findings are also expected to provide an additional insight to policymakers, especially central bank as monetary authority doe to the possibly occurring risks caused by the money circulation instability in economy.

Keywords: Debit Card; Credit Card; Money Velocity; Vector Error Correction

Model

JEL Classification: G18, G23, G28

\& Azhar, Z. (2021). Debit and

Credit Cards: Money Velocity Risks.

Jurnal Ekonomi \& Studi

Pembangunan, 22(2), 228-243.

\section{ARTICLE HISTORY}

Received:

24 Feb 2021

Revised:

29 Apr 2021

18 Jun 2021

$13 \mathrm{Jul} 2021$

11 Sep 2021

Accepted:

20 Sep 2021

\section{Introduction}

Financial innovation has received a lot of attention from financial literacy in the last few decades (Fiordelisi et al., 2010). The development of financial innovation, especially in the payment system, has encouraged banks throughout the world to make innovations resulting in new non-cash-based financial and payment systems, such as card-based payment instruments in the forms of Automatic Teller Machine (ATM) as well as credit, debit, and prepaid cards. The regulation related to card-based transactions was first issued by Bank Indonesia at the end of 2004. The provisions related to cardbased payment instruments have been regulated in Bank Indonesia Regulation No.7/52/PBI/2005. However, this regulation was integrated with the regulations for implementing the electronic money activities.

Until 2009, the regulation on card-based payment instruments was officially separated from the electronic money regulation and a new regulation was made in Bank Indonesia Regulation No. 11/11/PBI/2009 on the operation of card-based payment instrument activities (Bank Indonesia, 2009). 
ATM card is a card-based payment instrument used to make cash withdrawals and/or transfers of funds in which the cardholder's obligations are should be immediately fulfilled and by directly reducing the cardholder's deposits at the authorized bank or non-bank institution to raise funds under the prevailing laws and regulations. Conversely, a debit card is a card-based payment instrument used to make payments for obligations from various economic activities, including shopping transactions, in which the cardholder's obligations should be immediately fulfilled by directly reducing the cardholder's deposits at the authorized bank or non-bank institution to raise funds following the provisions of the applicable laws.

The non-cash payment instruments have recently developed and increasingly been used by the public. This fact shows that non-cash payment services provided by bank and nonbank institutions, in the process of sending funds, clearing operators, and settlement systems are already available and possibly held in Indonesia. It is assumed that the level of public interest in using non-cash payment instruments can affect the demands for cash and stability of money circulation in a country. This is confirmed by (Alih et al., 2018; Rahayu \& Nugroho, 2020) explaining that more sophisticated payment system makes people use electronic money more and more. This has an impact on the continuously decreasing use of cash and checks in the society. The rapid development of technology has changed the role and function of money in which when making a transaction, a person no longer needs cash but he/she can use alternative payment instruments to replace cash, such as credit and debit cards. In the study conducted by (Pandhit, 2020), to stimulate an efficient economy and expand the banking activities of Indonesian people is to perform financial inclusion. The indicators used are the ownership of credit and debit card as well as domestic credit ratios. The recommendation given is that the government in the ASEAN 8 regions should encourage and facilitate the expansion and acceleration of access to financial technology to the public and massively and fairly accelerate the implementation of financial inclusion for wider communities.

This phenomenon makes money easily transferred and changed from hands to hands and makes digital money slowly replace cash (Reiss, 2018). Financial innovations, such as the issuance of credit and debit cards can reduce the stability of money velocity. (Ghasani, 2015; Lintangsari et al., 2018) explained that non-cash payment transactions can affect the money velocity in which the increasing volume of non-cash payment transactions made by the society will increase the money velocity. Reaffirming the effect of financial innovation on money velocity. (Sarwono, 2003) explains that the rapid development in financial sector reduces the ability of central bank to control the amount or quantity of money in circulation. Due to the rapid innovation of financial products and processes, the creation of money in circulation will increasingly occur outside the monetary authority. This development causes the stability of money demand equation, multipliers, and velocity to be disturbed.

Many countries have implemented card-based non-cash payment systems for transactions, including Indonesia. The popularity of card payment instruments can be seen from a large number of card payment transactions in Indonesia. Based on Graph 1, it is known that card-based payment transactions can fluctuate over time. Even though in 
the previous period the total card-based non-cash transactions increased, a dramatic decrease may still occur in the next period, and vice versa.

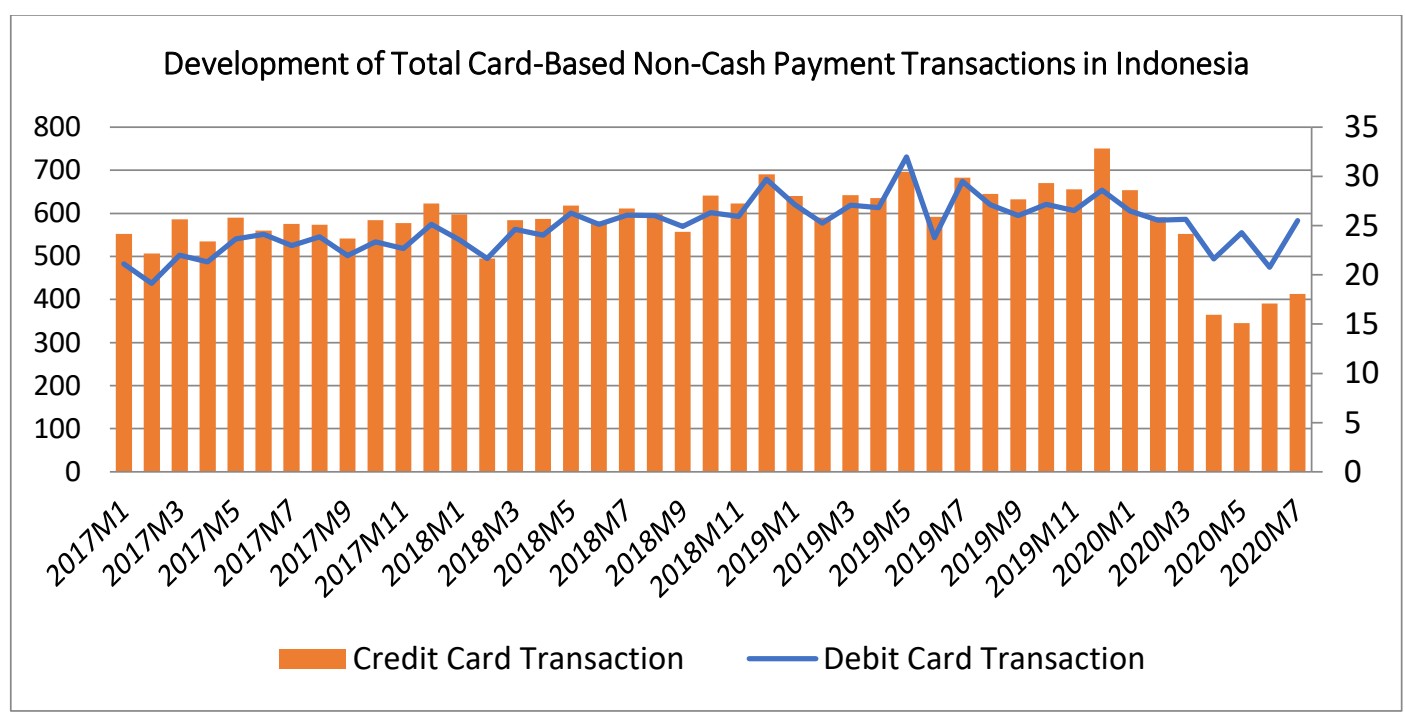

Figure 1 Development of card-based non-cash payment transactions in Indonesia (Million Rupiahs)

Source: Bank Indonesia

The positive movement trend of total card-based non-cash transactions, indirectly capturing the phenomenon that people's habits in transactions have recently changed leading to a cashless society in which the role of cash has slowly started fading in the society. Some elements of central bank policy, such as restrictions on cash demand and money circulation in Indonesia will be disrupted. The findings of non-cash payment risks on monetary and financial stability are also highlighted in the following literature. As stated by (Alih et al., 2018), neglecting financial innovation can lead to specification errors in determining the money demand levels. Unstable money velocity, unpredictable changes in money demands, and problems, such as a biased money demand outcome may occur.

Supported by (Choi, 2019; Dunne \& Kasekende, 2018; Xu et al., 2020), financial innovation is found as an important variable in determining and harming money demand. According to the research conducted by (Wei, 2018), the existence of continuous financial innovation will affect people's lifestyles and a country's economic growth, especially the distribution of third-party payments to cash circulation. The substitutional effect generated by this payment innovation is significant and at the same time, decreases the cash demand, increases the bank's commercial credit creation ability, money supply, and accelerates money circulation money in economy. In addition, (Jiang \& Shao, 2020) explains that the amount of money in circulation is a significant part of central bank's balance sheet, while the decreasing cash demand will have important implications for seigniorage income, independence, and the ability of central bank to conduct the monetary policy. 
The development of card-based non-cash payment instruments, such as ATMs and debit cards with savings as the underlying causes a shift in the function of savings from deposits which cannot be withdrawn any time to become those withdrawn any time, similar to the demand deposits. Thus, it is necessary to consider the classification of savings using ATM or debit card as a part of narrow money (M1) in the demand deposit category instead of M2. Inaccurate classification of monetary quantities can have implications for errors in the formulation and implementation of monetary policy using monetary quantities as the operational targets (Pramono et al., 2006).

Money velocity is used to measure the circulation rate of one money unit used to make transactions in economy. Money velocity is a measure of how many times an average currency unit is used to buy goods and services in a certain period (Aliyu \& Dodo, 2021). The notion connects the size of economic activity to a particular money supply and one element determining inflation is money exchange rate. Central bank can control the price (P) by targeting $\mathrm{M}$. This is the importance of monitoring and ensuring the money velocity. For central banks which use the monetary amounts as their operational and final target, money velocity is an important indicator required more attention. Money is a measure of number of times related to the average unit of currency used in the transaction process over a certain period. This concept relates the measure of economic activity to the money supply and money exchange rate. Money velocity must be predictable and stable. Money velocity is used to measure the circulation rate of one money unit used to make transactions in economy.

Innovations in financial market, such as the issuance of non-cash payment instruments, are believed to reduce the stability of money velocity. From the explanation of money demand theory (Mankiw, 2019), it can be concluded that several factors affect the money velocity circulation, including form of institutions and technology in economy affecting the behavior of individuals making transactions, as well as the amount of income, money demand, price level, and interest rates. The existence of financial innovation as a result of rapid development of technology, especially in banking sector, is believed changing people's behavior in transactions. The issuance of card-based non-cash payment instruments is assumed to be one factor reducing the use of cash and increasing the efficiency of transaction settlement time, this, of course, will have an impact on the stability of money velocity and be able to change the function of money demand (Gintting et al., 2019).

A good understanding on money velocity is important in establishing a credible and targeted monetary policy program. Thus, this payment instrument innovation needs special attention from policy-making institutions, such as Central Bank to pay more attention to the impact of financial innovations and create the targeted monetary policies and actions for the sake of creating stability in a country's financial system. The calculation of monetary amount related to the progress of non-cash payments needs to be well improved. Most previous studies only focused on one payment instrument using a card and there are only limited literatures comparing the effect of all payment instruments using cards (debit and credit card) on money velocity or amount of money in circulation. 
Thus, further research is needed related to the impact of innovation of payment system using cards in monetary sphere. This is an interesting study to conduct, especially in Indonesia, given a large number of people with a fairly consumptive society and classified as an emerging market. Money velocity is interesting to study because it is greatly influential related to the effectiveness of monetary policy implementation. In-depth analysis on the impact of payment innovation on money velocity is greatly important to become a reference for monetary authorities in making policies and anticipating the impact of changes in money velocity in economy. One important focus of this research is to find out how money velocity responds to the use of card-based non-cash transaction tools occurring in Indonesia. Money velocity can be described from the ratio between base money and nominal gross domestic product. Therefore, this study aims to determine the effect of using a payment instrument like credit and debit cards on money velocity in Indonesia for long and short terms.

\section{Research Method}

This study examined the impact of payment transactions using cards represented by (credit and debit cards) on money velocity in Indonesia, using control variables of interest rates and inflation describing a country's economic conditions. Money velocity is described by the ratio between the amount of money in circulation, in this study taking based money (MO) and nominal GDP. Because this research focused on identifying and analyzing the impact of card-based payment transactions on money velocity circulation, the research period started from 2016M1 to 2020M6. The reason was that the researchers tried to get more accurate results under the current situation. The selection of monthly data was expected to provide more accurate results. This study used the secondary data in the form of time series sourced from the websites of Bank Indonesia and Statistics Indonesia. To see the effect of independent variables on money velocity circulation in Indonesia, several analytical tests were performed including data stationarity test using augmented dickey fuller (ADF), determining lag length using the Akaike Information Criterion (AIC), and Engle-Granger co-integration test or Augmented Engle-Granger (AEG) and Classical Assumption Test consisting of Normality Test, Multicollinearity Test, Heteroscedasticity Test, and Autocorrelation Test. Finding that there was cointegration between variables in the study, the appropriate model used in this literature is VECM model. VECM is an econometric model used to determine a variable's short-run to long-run behavior (Anis et al., 2019). In addition, VD and IRF tests were also performed.

The VECM model to test the effect of card payment on money velocity circulation in this study is:

$$
\Delta v_{t}=\beta_{0}+\sum_{i=0}^{n} \beta_{2 i \Delta C D_{t-1}}+\sum_{i=0}^{n} \beta_{3 i \Delta D C_{t-1}}+\sum_{i=0}^{n} \beta_{4 i \Delta R_{t-1}}+\sum_{i=0}^{n} \beta_{5 i \Delta I N F_{t-1}}+\beta_{6 i} E C T_{t-1}+\varepsilon_{t}
$$


Where: $\Delta v_{t}$ : Money Velocity, $C D_{t}$ : Credit card transactions, $D C_{t}$ : Debit card transactions, $R_{t}$ : Interest rate, $I N F_{t}$ : Inflation rate, $\alpha_{n i}$ : Constant, $\varepsilon_{t}$ : Error coefficient or noise factor, $i, n$ : Long lag, ECT : Error correction term or error disequilibrium.

\section{Result and Discussion}

Stationarity Test Results

The stationarity test was conducted to see whether or not the data used in this study were stationary. Based on the following processed results, it can be seen that all variables in this study were stationary at the first difference level proven by comparing the ADF Test Statistical value which was greater than the critical value. This fact was also supported by the comparison of probability value of each variable that was respectively smaller than the alpha level of $1 \%, 5 \%, 10 \%$.

Table 1 Stationarity test results

\begin{tabular}{lccccc}
\hline \multicolumn{1}{c}{ Variable } & $\begin{array}{c}\text { Unit Root Test } \\
\text { on }\end{array}$ & $\begin{array}{c}\text { ADF Test } \\
\text { Stat. }\end{array}$ & $\begin{array}{c}\text { Critical Values } \\
5 \%\end{array}$ & Prob.* & Information \\
\hline $\begin{array}{l}\text { Money } \\
\text { Velocity }\end{array}$ & $1^{\text {st }}$ Difference & -3.218523 & -2.933158 & 0.0258 & Stationary \\
Debit Card & $1^{\text {st }}$ Difference & -14.74305 & -2.918778 & 0.0000 & Stationary \\
Credit Card & $1^{\text {st }}$ Difference & -10.04640 & -2.918778 & 0.0000 & Stationary \\
Interest Rate & $1^{\text {st }}$ Difference & -5.107005 & -2.918778 & 0.0001 & Stationary \\
Inflation & $1^{\text {st }}$ Difference & -6.783378 & -2.918778 & 0.0000 & Stationary \\
\hline
\end{tabular}

Lag Length Test Results

The optimal lag selection is greatly beneficial to overcome the autocorrelation problems. In this study, the optimal lag selection was based on the sequential modified LR test statistical criteria in which the optimal lag was in lag 1.

Table 2 Optimal lag length test results

\begin{tabular}{ccccc}
\hline Lag & LR & AIC & SC & HQ \\
\hline 0 & NA & -5.992866 & $-5.660465^{*}$ & -5.920055 \\
1 & $64.22802^{*}$ & $-6.452593^{*}$ & -5.305379 & $-6.015728^{*}$ \\
2 & 30.89806 & -6.244851 & -4.141626 & -5.443931 \\
3 & 22.59480 & -5.909404 & -2.850167 & -4.744429 \\
\hline
\end{tabular}

\section{Co-integration Test Results}

As stated by (Engle \& Granger, 1987), a linear combination of two or more non-stationary time series variables may be stationary. If the combination of these non-stationary variables produces a stationary residual, then the variables are said to be cointegrated. It means that there is a long-run relationship between variables in the VECM system. The next step in VECM estimation is a cointegration test to determine the existence of a long- 
run relationship between variables to know whether or not the model used is a differentiation level of VAR model (if there is no cointegration) or of VECM model (if there is cointegration). Based on the Table 3 , it can be seen that the trace statistical value is greater than the critical value with a significance level of $5 \%$. It means that there is cointegration for the data in this study showing that there is a long-run balance between various variables used in this study. The data co-integration shows that the appropriate model to use is the VECM model.

Table 3 Co-integration test results

\begin{tabular}{lccc}
\hline Hypothesized CE(s)No. & Trace Statistics & Critical Value of 0.05 & Prob.** \\
\hline None* & 157.3789 & 69.81889 & 0.0000 \\
At most 1* & 108.9866 & 47.85613 & 0.0000 \\
At most 2* & 66.13068 & 29.79707 & 0.0000 \\
At most 3* & 33.11735 & 15.49471 & 0.0001 \\
\hline At most 4* & 6.864638 & 3.841466 & 0.0088 \\
\hline
\end{tabular}

Granger's Causality Test

The Granger causality test analysis in this study shows that there was a one-way causality relationship between money velocity $(V)$ and credit card $(C D)$, where money velocity $(V)$ statistically and significantly affected credit card (CD). There was also a two-way causality relationship between money velocity (V) and inflation (INF). Meanwhile, debit card and interest rate $(R)$, had a one-way causality relationship, where credit card $(C D)$ statistically and significantly affected interest rate $(\mathrm{R})$. This was indicated by the probability value of each variable which was smaller than the alpha level of 0.05 .

Table 4 Granger's causality test

\begin{tabular}{cccc}
\hline Lag & \multicolumn{1}{c}{ Null Hypothesis } & F-Statistics & Prob. \\
\hline 1 & DC is not Granger Causing V & 0.55872 & 0.4583 \\
& V is not Granger Causing DC & 4.55187 & 0.0378 \\
\multirow{2}{*}{1} & CD is not Granger Causing V & 1.33603 & 0.2532 \\
& V is not Granger Causing CD & 2.92152 & 0.0936 \\
\multirow{2}{*}{1} & R is not Granger Causing V & 2.35964 & 0.1308 \\
& V is not Granger Causing R & 0.15708 & 0.6935 \\
\multirow{2}{*}{1} & INF is not Granger Causing V & 6.33614 & 0.0151 \\
& V is not Granger Causing INF & 7.41758 & 0.0089 \\
\multirow{2}{*}{1} & R is not Granger Causing DC & 0.03869 & 0.8449 \\
& DC is not Granger Causing R & 3.64910 & 0.0618 \\
\multirow{2}{*}{1} & INF is not Granger Causing DC & 0.95401 & 0.3334 \\
& DC is not Granger Causing INF & 0.60941 & 0.4387 \\
\multirow{2}{*}{1} & R is not Granger Causing CD & 0.60601 & 0.4400 \\
& CD is not Granger Causing R & 4.10501 & 0.0481 \\
\multirow{2}{*}{1} & INF is not Granger Causing CD & 0.12195 & 0.7284 \\
& CD is not Granger Causing INF & 0.83422 & 0.3654 \\
\multirow{2}{*}{1} & INF is not Granger Causing R & 0.03466 & 0.8531 \\
& R is not Granger Causing INF & 0.00350 & 0.9531 \\
\hline
\end{tabular}


VECM Model of Money Velocity in Indonesia

The VECM test results can be seen in the following Table 5 to determine the relationship between debit card transaction, credit card, interest rate, and inflation rate on money velocity in Indonesia. It can be seen by comparing the t-statistic value with the t-table. If the $t$-statistical value is greater than the $t$-table, it can be said that the independent variable affects the dependent variable. The t-table value is based on the $t$ frequency distribution table, with a df of 46 and a probability of 0.05 in a two-way test of 2.01290 . Thus, if the t-statistic value is greater than 2.01290 , it can be concluded that the independent variable has a significant effect on the dependent variable. Based on the table of VECM estimation results for money velocity circulation in Indonesian, it can be seen that in a long run, all independent variables had a significant effect on the dependent variable. The variable is credit card transaction (DC), debit card transaction (CD), interest rate $(\mathrm{R})$, and inflation rate.

Table 6 VECM estimation results on money velocity in Indonesia

\begin{tabular}{|c|c|c|c|}
\hline \multicolumn{4}{|c|}{ Long-run } \\
\hline Variable & Coefficient & T-statistical value & $\begin{array}{c}\text { Information } \\
\text { (t-table }=2.01290)\end{array}$ \\
\hline$V(-1)$ & & 1.000000 & \\
\hline $\operatorname{LOG}(\mathrm{DC}(-1))$ & 0.580147 & 4.98344 & Significant \\
\hline $\operatorname{LOG}(\mathrm{CD}(-1))$ & -0.482190 & -3.54230 & Significant \\
\hline $\mathrm{R}(-1)$ & -0.034948 & -4.69717 & Significant \\
\hline INF(-1) & -0.084968 & -4.92353 & Significant \\
\hline C & & -5.169439 & \\
\hline \multicolumn{4}{|c|}{ Short-run } \\
\hline Variable & Coefficient & T-statistic value & $\begin{array}{c}\text { Information } \\
(\mathrm{t} \text {-table }=2.01290)\end{array}$ \\
\hline CointEq1 & -1.218881 & -3.82054 & Significant \\
\hline $\mathrm{D}(\mathrm{V}(-1))$ & 0.162657 & 0.61778 & Not significant \\
\hline $\mathrm{D}(\mathrm{V}(-2))$ & 0.116156 & 0.53761 & Not significant \\
\hline $\mathrm{D}(\operatorname{LOG}(\mathrm{DC}(-1)))$ & -0.068926 & -016549 & Not significant \\
\hline $\mathrm{D}(\operatorname{LOG}(\mathrm{DC}(-2)))$ & -0.041998 & -0.10081 & Not significant \\
\hline $\mathrm{D}(\operatorname{LOG}(\mathrm{CD}(-1)))$ & 0.002947 & 0.01058 & Not significant \\
\hline $\mathrm{D}(\operatorname{LOG}(\mathrm{CD}(-2)))$ & -0.003711 & -0.01265 & Not significant \\
\hline$D(R(-1))$ & -0.065984 & -0.99442 & Not significant \\
\hline $\mathrm{D}(\mathrm{R}(-2))$ & 0.014946 & 0.22716 & Not significant \\
\hline $\mathrm{D}(\mathrm{INF}(-1))$ & -0.019048 & -0.39279 & Not significant \\
\hline $\mathrm{D}(\mathrm{INF}(-2))$ & -0.039786 & -0.81452 & Not significant \\
\hline $\mathrm{C}$ & -0.011819 & -0.80876 & Not significant \\
\hline
\end{tabular}

In a short run, both lag 1 and 2 did not have a variable which significantly affected money velocity circulation in Indonesia. However, this relationship had a long-run balance indicated by its negative ECT value. Furthermore, a long-run equation for money velocity in Indonesia can be formed as follows:

$V=-5.169439+0.580147 \log D C-0.4821190 \log C D-0.034948 R-0.084968 I N F$ 
From the above equation, it can be concluded that several variables had a positive relationship with money velocity circulation, while several other variables had a negative relationship. The variable having the most dominant influence on money velocity circulation in Indonesia was debit card transaction, while that having the weakest effect in $\mathrm{R}$ was interest rate. It shows that card-based non-cash payment transaction had a higher ability to affect money velocity circulation in Indonesia.

This condition was in line with that conducted by (Lukmanulhakim et al., 2016) in which card-based payment transaction could affect money velocity. If more people use credit and debit cards for transactions, the money velocity in economy will change. The VECM estimation results show that these two non-cash payment instruments had a significant effect on money velocity in Indonesia. However, different types of payment instruments had the opposite relationships in affecting money velocity. Payment transactions using debit cards had a significant and positive relationship with money velocity. It means that the increasing debit card transactions increase, will be followed by the increasing money velocity in Indonesia. 1 percent increase on debit card will be followed by an increase of 0.580147 or 58.01 percent on the value of money velocity. This value indicates that money velocity is very elastic because the value of changes in money velocity is higher than that in debit card transactions.

The results of this study are in line with those of research conducted by (Aliha et al., 2019) finding that the development of technology and banking, such as the debit card creation can increase money velocity. The increased use of debit cards will be followed by the decreasing cash demands in the society and result in the increasing money circulation in economy increase. The findings related to the use of debit cards can increase the money circulation in economy as expressed by (Dunne \& Kasekende, 2018) in his research, that debit and ATM cards have the potential to increase efficiency and decrease transaction costs because the cash to bring is replaced by innovation in payment instruments causing a decreasing public demand for cash and rapid money velocity.

Unlike debit card, as seen from the equation of estimation results above, the use of credit cards in Indonesia has a significant negative effect on money velocity. When there is 1 percent credit card increase, it will be followed by a decreasing value of money velocity by 0.4821190 or 48.21 percent. This is in line with the research conducted by (Jiang \& Shao, 2020) in his literature, explaining that credit card expansion affected cash credit sector in which he argued that new payment instruments (credit cards) resulted in cash dropping to other payment instruments in the selling point. The development of new payment instruments has a potential to affect the public demand for cash and cause the decreasing money circulation in economy. Currencies in circulation have significantly made a part of central bank balance sheets, decreasing currency demand with important implications for seigniorage income, independence, and ability of central banks to conduct the monetary policy.

However, different results were also found in this study, as mentioned by (Geanakoplos \& Dubey, 2010) in their literature that the widespread use of credit cards can increase trade efficiency, yet the use of credit cards also increases money velocity leading to 
inflation without any monetary intervention. Similarly, the research conducted by (Alih et al., 2018) stating that credit card variable has a positive and significant impact on the incoming money demand in a long run. It can be concluded from the above studies that the use of credit cards doesn't decrease but increase the money supply. However, the results of this study are in line with (Aliha et al., 2019) in which the increasing credit card use can reduce the cash demand in society and result in the slowing money circulation in society. Similarly, both interest rate and inflation, have a significant and positive effect on money supply, while interest rate has a significant and negative effect on money velocity. Variance Decomposition (VD) Analysis Results

Variance Decomposition is a prediction related to the percentage contribution of each particular variable's variance. However, we can generally expect that the largest proportion of variance comes from the variable itself. Thus, the use of Variance Decomposition was intended to obtain an overview the strength of role composition to certain variables.

Table 7 Variance decomposition results

\begin{tabular}{ccccccc}
\hline Period & S.E. & V & LOG(DC) & LOG(CD) & R & INF \\
\hline 1 & 0.094315 & 100.0000 & 0.000000 & 0.000000 & 0.000000 & 0.000000 \\
5 & 0.126181 & 70.71722 & 0.975518 & 20.73661 & 3.333495 & 4.237155 \\
10 & 0.163246 & 64.10740 & 1.203576 & 25.06789 & 5.736272 & 3.884781 \\
\hline
\end{tabular}

Table 7 shows that the largest contribution affecting money velocity circulation came from its growing variance. The highest contribution in a short term was 100 percent in the first period, it means that only money velocity circulation affects itself, while in the 5th period, this proportion decreased to 70.71 percent and other variables which have the largest proportion influencing money velocity circulation in Indonesia respectively consisting of $\mathrm{CD}$, credit card transactions; and INF, inflation rate in Indonesia. Furthermore, the influence proportion of money velocity for itself decreased to 64.10 percent in the 10th period. In this period the largest contribution was made by $C D$, known as the trend of credit card-based non-cash payment transactions, reaching up to 25.06 percent.

\section{IRF Analysis Results (Impulse Response Function)}

According to (Basuki \& Prawoto, 2016), the IRF analysis can explain the impact of shocks on one variable to the other variables. This analysis was not only in short-term but also for several horizons in the future as a long-term information. The Impulse Response Function aimed to track the current and future responses of each variable due to a change or shock of a particular variable. In this variable, shock was seen in the payment transaction variable using both debit and credit cards to determine the response to the money velocity circulation in Indonesia. Based on Figure 2, the IRF results show how the response of money velocity variable shocks and occurs in the debit card variable. It can be seen in the first and second period that shock on debit cards shows a fairly flat response to the money velocity circulation, but shock from credit card was positively responded by the money velocity circulation in the third period to the end of fourth period. Finally, in the next period, the response value of money velocity to the shock of debit card which 
always approaches not only horizontal line but also zero. It means that in the eighth period, the money velocity was back to stable.

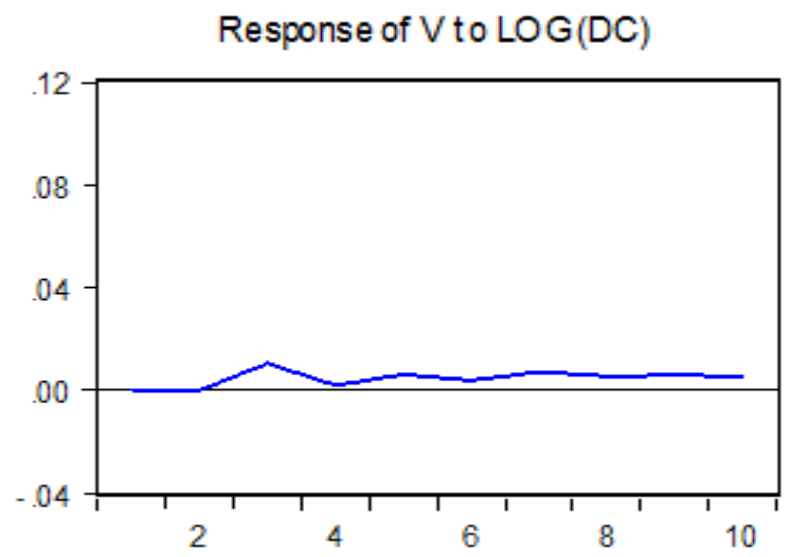

Figure 2 IRF test results on money velocity responses to debit cards in Indonesia

Furthermore, Figure 3 is the money velocity responses to the shock occurring on credit card variable in Indonesia. Meanwhile, based on Figure 3, it can be seen that the beginning of 2nd period, the shock occurring on credit cards was positively responded by money velocity circulation with its positive movements. However, in the third to fifth period, the movement in response to money velocity circulation showed a decrease, yet still positively responded. Both variables began to show their stability between shock and response from the 7 th to the next period.

Response of $V$ to LOG (CD)

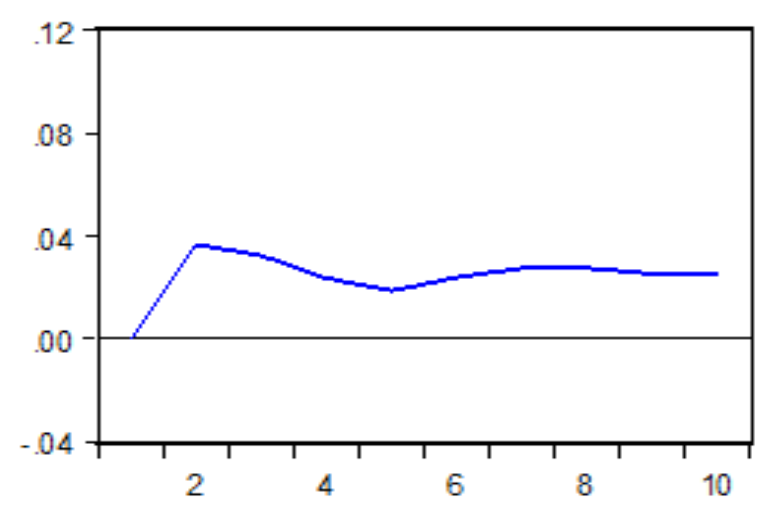

Figure 3 IRF test results on money velocity responses to credit cards in Indonesia

Figure 4 below shows that money velocity responses in Indonesia to the interest rate was positive. This condition can be seen from the reaction line above the zero-horizon line. This positive response was proven in the third period until reaching the end of period. Meanwhile, in Figure 5, it can be seen that money velocity in Indonesia gives a positive response to inflation. This positive response was proven starting from the shock to the third period. After the third period, the response shows a direction towards stability until the next period. 
Response of $\mathrm{V}$ to $\mathrm{R}$

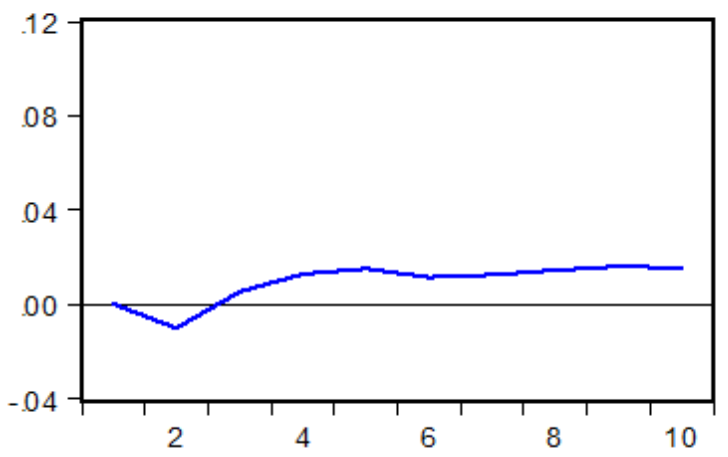

Figure 4 IRF Test results on money velocity response due to interest rate changes in Indonesia

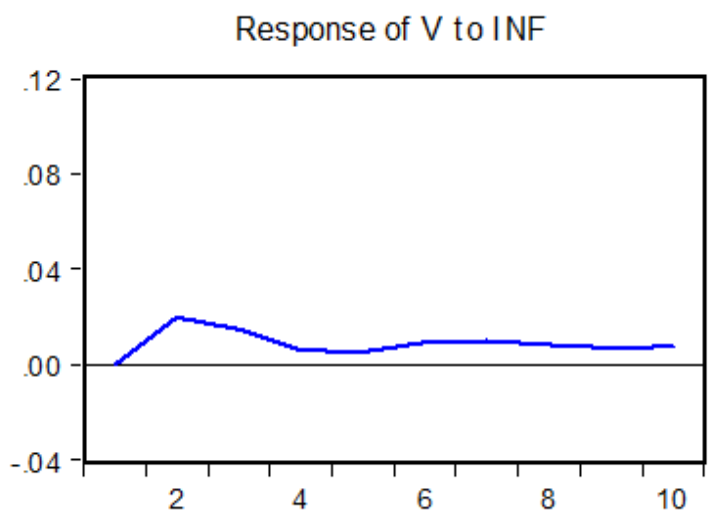

Figure 5 IRF test results on money velocity responses due to inflation changes in Indonesia

\section{Classical Assumption Test}

This test was conducted to determine whether or not there were deviations occurring in the research results in the regression equation. The classical assumption test consisted of normality, multicollinearity, heteroscedasticity, and autocorrelation test.

Normality Test

The normality test was intended to test whether or not the standardized residual value in the regression model was normally distributed. The residuals were tested using JarqueBera Test and resulted in normally distributed, it was proven by comparing the calculated Jarque-Bera probability value with the alpha level of 5 percent. It can be seen that the calculated JB probability value of 0.064284 was greater than the 5 percent alpha level value. Thus, it indicates that the residuals were normally distributed. 


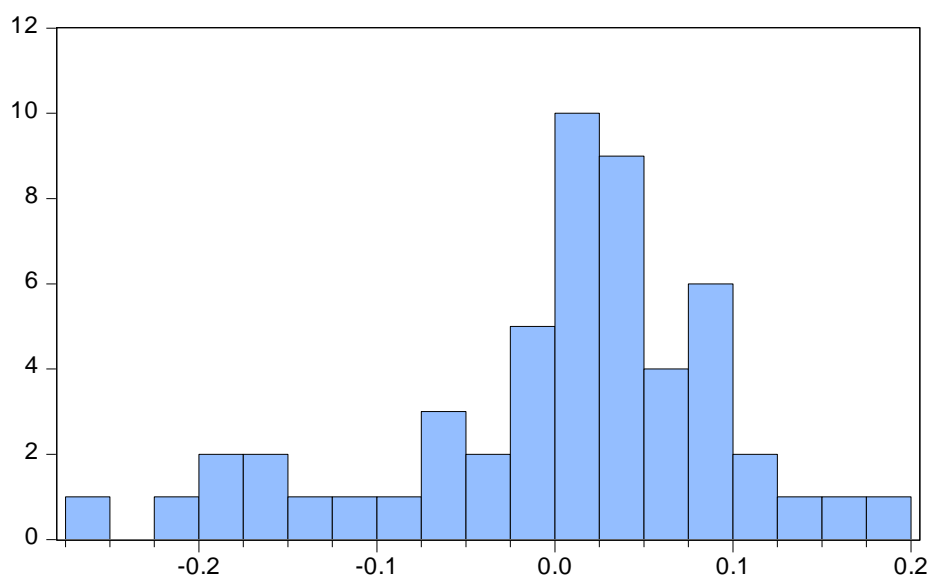

\begin{tabular}{lc}
\multicolumn{2}{l}{ Series: Residuals } \\
Sample 2016M02 2020M06 \\
Observations 53 \\
Mean & $1.70 \mathrm{e}-16$ \\
Median & 0.018326 \\
Maximum & 0.190108 \\
Minimum & -0.251821 \\
Std. Dev. & 0.094578 \\
Skewness & -0.773207 \\
Kurtosis & 3.306821 \\
& \\
Jarque-Bera & 5.488892 \\
Probability & 0.064284
\end{tabular}

Figure 6 Normality Test Results

Multicollinearity Test

The multicollinearity test in research was used to see whether or not there was a relationship (correlation) between the independent variables. If there is a relationship between the independent variables, then the regression coefficient tends to be insignificant. The Table 8 shows that all VIF values in the centered VIF column for each variable in the study did not exceed 10 . It indicates that there was no multicollinearity problem in this study.

Table 8 Multicollinearity test results

\begin{tabular}{ccc}
\hline Variable & Coefficient Variance & Centered VIF \\
\hline CD & $3.20 \mathrm{E}-17$ & 3.107464 \\
DC & $8.28 \mathrm{E}-20$ & 3.533868 \\
INF & 0.000643 & 1.590395 \\
R & 0.000173 & 1.070269 \\
C & 0.023176 & $\mathrm{NA}$ \\
\hline
\end{tabular}

\section{Heteroscedasticity Test}

Heteroscedasticity occurs when the residual and predictive values have a correlation or relationship pattern. The pattern of this relationship is not only linear, but also possibly different. The heteroscedasticity test in this study used Glejser method. If the prob value is smaller, there is a heteroscedasticity problem, but if the prob value is bigger, there is no heteroscedasticity problem.

Based on the above heteroscedasticity test results, it can be seen the Prob value. The ChiSquare of Obs*R-Squared of 0.9796 was greater than the 5 percent alpha level. It was proven that there was no heteroscedasticity problem in the research model. 
Table 9 Heteroscedasticity test results

\begin{tabular}{lccc}
\hline \multicolumn{4}{c}{ Heteroskedasticity Test: Glejser } \\
\hline F-statistic & 0.099261 & Prob. F(4,49) & 0.9822 \\
Obs*R-Squared & 0.434040 & Prob. Chi-Square(13) & 0.9796 \\
Scaled explained SS & 0.418849 & Prob. Chi-Square(13) & 0.9809 \\
\hline
\end{tabular}

\section{Autocorrelation Test}

Table 10 Autocorrelation test results

\begin{tabular}{lccc}
\hline \multicolumn{4}{c}{ Breusch-Godfrey Serial Correlation LM Test: } \\
\hline F-statistic & 2.866743 & Prob. F(2,47) & 0.0669 \\
Obs*R-squared & 5.871189 & Prob. Chi-Square(2) & 0.0531 \\
\hline
\end{tabular}

The next step in classical assumption is to perform an autocorrelation test. The autocorrelation test in this study used Breusch-Godfrey Serial Correlation LM Test. The test results show that there was no autocorrelation problem as evidenced by the Prob value. The Chi-Squared of Obs*R-Squared was 0.0531 greater than the 5 percent alpha level value.

\section{Conclusion}

The relationship between financial innovation and money supply is indeed familiar in financial literature, but how financial innovation affects performance and movement of money velocity is greatly important to be explored further. This study looks at this relationship through the measured money velocity variable, with a comparison between the ratio of nominal GDP and money supply (MO). Thus, some conclusions are drawn as follows: (1) money velocity in a short run doesn't show a significant effect on financial innovation, namely debit card transactions in Indonesia, but this effect changes into significant and positive on money velocity in a long run. It indicates that money velocity is greatly sensitive to the debit card expansion in Indonesia. The positive relationship between money velocity and debit card transactions proves the hypothesis that transitions from cash to non-cash (using debit cards) increases money velocity in Indonesia. (2) Money velocity in a short run does not show a significant effect on the use of credit cards in Indonesia, but in a long run, this card-based payment instrument (credit card) has a significant and negative effect on money velocity in Indonesia, showing that innovation credit-card payment instruments dominate the market in Indonesia. The negative relationship between money velocity and credit card catches a shock on money velocity due to credit transactions, where money velocity has actually decreased due to the increasing use of credit cards in Indonesia.

The existence of significant relationship between money velocity and card-based noncash transactions in Indonesia, in a long run, indicates that it needs caution for policymakers in making decisions. Indirectly, this long-run relationship explains that Central Bank can enter and influence people's transaction behaviors. Meanwhile, currency circulation is a significant part of central bank's balance sheet. The decreasing currency demand will have some important implications to central bank's seigniorage 
income, independence, and ability to conduct monetary policy. Therefore, it is important to monitor and understand the money velocity trend to provide benefits in a long run.

This study has several limitations in describing the relationship between debit card transactions and money velocity in Indonesia. The relationship between debit card and money velocity is positive. Meanwhile, the expected relationship based on theory is negative. This is possibly because the data are limited. For future researchers conducting similar topics are suggested to improve the limitations of this study.

\section{References}

Alih, P. M., Sarmidi, T., Shaari, A. H., \& Said, F. F. (2018). Investigating the relationship between financial innovation and money demand in Malaysia: an ARDL approach to co-integration. International Journal of Accounting, Finance and Business, 3(15), 66-85.

Retrieved from http://www.ijafb.com/PDF/IJAFB-2018-15-12-07.pdf

Aliha, P. M., Sarmidi, T., \& Said, F. F. (2019). Exploring money demand dynamics in Malaysia with the inclusion of financial innovations. International Journal of Advanced Research in Economics and Finance, 1(2), 1-14. Retrieved from https://myjms.mohe.gov.my/index.php/ijaref/article/view/7098

Aliyu, A. B., \& Dodo, E. (2021). Impact analysis of changes in money supply on price shocks in Nigeria. Indian Journal of Finance and Economics, 2(1), 73-87. Retrieved from https://arfjournals.com/abstract/43207 6 abubakar_bilkisu.pdf

Anis, A., Putra, H. S., Alfarina, N., \& Azhar, Z. (2019). Analysis of the effectiveness of monetary policy transmission (evidence in Indonesia and Thailand). Proceedings of the Third Padang International Conference on Economics Education, Economics, Business and Management, Accounting and Entrepreneurship (PICEEBA 2019). https://doi.org/10.2991/piceeba-19.2019.9

Bank Indonesia. (2009). Peraturan Bank Indonesia Nomor 11/11/ PBI/2009. Retrieved from https://peraturan.bpk.go.id/Home/Download/128445/Peraturan\%20BI\%20No.\%2 011-11-PBI-2009.pdf

Basuki, A.T., \& Prawoto, N. (2016). Analisis regresi dalam penelitian ekonomi \& bisnis: dilengkapi aplikasi SPSS \& EVIEWS (2nd ed.). Yogyakarta: Rajagrafindo.

Choi, H. S. (2019). Money, debit card, gross-settlement risk, and central banking. The North American Journal of Economics and Finance, 50, 100993. https://doi.org/10.1016/j.najef.2019.100993

Dunne, J. P., \& Kasekende, E. (2018). Financial innovation and money demand: evidence from Sub - Saharan Africa. South African Journal of Economics, 86(4), 428-448. https://doi.org/10.1111/saje.12205

Engle, R.F., \& Granger, C. W. J. (1987). Co-integration and error correction: representation, estimation, and testing. Econometrica, 55(2), 251-276. Retrieved from http://links.jstor.org/sici?sici $=0012-$ 9682\%28198703\%2955\%3A2\%3C251\%3ACAECRE \%3E2.0.CO \%3B2-T

Fiordelisi, F., Molyneux, P., \& Previati, D. (Eds.). (2010). New issues in financial institutions management. https://doi.org/10.1057/9780230299153

Geanakoplos, J., \& Dubey, P. (2010). Credit cards and inflation. Games and Economic Behavior, 70(2), 325-353. https://doi.org/10.1016/i.geb.2010.02.004 
Ghasani, H. (2015). Analisis Vector Auto Regressive (VAR) volume transaksi e-money terhadap velocity of money di Indonesia tahun 2009-2012. Under Graduates Thesis. Universitas Negeri Semarang.

Gintting, Z., Djambak, S., \& Mukhlis, M. (2019). Dampak transaksi non tunai terhadap perputaran uang di Indonesia. Jurnal Ekonomi Pembangunan, 16(2), 44-55. https://doi.org/10.29259/jep.v16i2.8877

Jiang, J. H., \& Shao, E. (2020). The cash paradox. Review of Economic Dynamics, 36, 177-197. https://doi.org/10.1016/j.red.2019.09.003

Lintangsari, N. N., Hidayati, N., Purnamasari, Y., Carolina, H., \& Ramadhan, W. F. (2018). Analisis pengaruh instrumen pembayaran non-tunai terhadap stabilitas sistem keuangan di Indonesia. Jurnal Dinamika Ekonomi Pembangunan, 1(1), 47-62. https://doi.org/10.14710/jdep.1.1.47-62

Lukmanulhakim, M., Djambak, S., \& Yusuf, M. (2019). Pengaruh transaksi non tunai terhadap velositas uang di Indonesia. Jurnal Ekonomi Pembangunan, 14(1), 41-46. Retrieved from https://ejournal.unsri.ac.id/index.php/jep/article/view/8774

Mankiw, N. G. (2019). Macroeconomis, $10^{\text {th }}$ Edition. Worth Publishers.

Pandhit, T. S. L. (2020). Dynamic financial inclusion in ASEAN 8: do macroeconomics and financial technology matter? Jurnal Ekonomi \& Studi Pembangunan, 21(2), 146-160. http://dx.doi.org/10.18196/jesp.21.2.5037

Pramono, B., \& Yanuarti, T., Purusitawati, P.D., \& Emmy, Y.T. (2006). Dampak pembayaran non tunai terhadap perekonomian dan kebijakan moneter. Working Paper Bank Indonesia, No WP/11/2006.

Rahayu, S., \& Nugroho, R. Y. Y. (2020). Dampak pembayaran non tunai terhadap percepatan perputaran uang di Indonesia. BISEI: Jumal Bisnis dan Ekonomi Islam, 5(1), 15-26. Retrieved from http://ejournal.unhasy.ac.id/index.php/bisei/article/view/716

Reiss, D. G. (2018). Is money going digital? An alternative perspective on the current hype. Financial Innovation, 4(1). https://doi.org/10.1186/s40854-018-0097-x

Sarwono, H. A., \& Warjiyo, P. (2003). Mencari paradigma baru manajemen moneter dalam sistem nilai tukar fleksibel: suaru pemikiran untuk penerapannya di Indonesia. Buletin Ekonomi Moneter dan Perbankan, 1(1), 5-23. https://doi.org/10.21098/bemp.v1i1.158

Wei, M. (2018). An Empirical Analysis of the Impact of Internet Finance on Money Supply. Proceedings of the 2018 International Conference on Economics, Business, Management and Corporate Social Responsibility (EBMCSR 2018). https:// doi.org/10.2991/ebmcsr$\underline{18.2018 .19}$

Xu, X., Chen, R., \& Jiang, L. (2020). The influence of payment mechanisms on pricing: when mental imagery stimulates desire for money. Journal of Retailing, 96(2), 178-188. https://doi.org/10.1016/i.jretai.2019.08.002 